\title{
Effect of Wheatgrass (Triticum aestivum) Juice on High Density Lipoprotein (HDL) Level in Experimentally Induced Dyslipidaemic Male Long Evans Rat
}

\author{
Rokhsana Dil Afroz ${ }^{1}$, Abu Sadat Mohammad Nurunnabi², Md. Ismail Khan ${ }^{3}$, Tuhin Jahan ${ }^{4}$
}

\begin{abstract}
Background: Evidence shows that high density lipoproteins (HDLs) may exert multiple anti-atherogenic and anti-thrombotic effects that together decrease the risk of cardiovascular morbidity in hyperlipidaemic state. Experimental studies showed that fresh wheatgrass (Triticum aestivum Linn.) juice exerts lipid lowering effect as well as increases HDL-cholesterol level in rats. Objective: The present study was done to observe the effect of wheatgrass juice on serum HDL-cholesterol on experimentally induced dyslipidaemic rats evident by reduced HDL-cholesterol level. Materials and method: This experimental study was carried out in the Department of Pharmacology \& Therapeutics, Dhaka Medical College, Dhaka, from July 2009 to June 2010. A total number of 48 healthy adult male Long Evans rats, age ranging from 2-3 months, and weighing from 140-200 grams were used for the present study. Six rats were taken in each group of total 8 groups treated differently with 1 control group. Rats of the first 5 groups were sacrificed at 29th day and their lipid profile was measured. Rests of the rats were sacrificed at 57th day and their lipid profile was measured. Results: Mean $H D L$-cholesterol of the group of rats treated with $10 \mathrm{~mL} / \mathrm{kg}$ grass juice and $1 \%$ cholesterol diet, with $10 \mathrm{~mL} / \mathrm{kg}$ grass juice and with $20 \mathrm{~mL} / \mathrm{kg}$ grass juice were significantly increased $(P<0.05, \quad P<0.05, \quad P<0.01$ respectively). The mean $H D L$-cholesterol of the group treated with Atorvastatin for 28 days were also significantly increased $(P<0.001)$. Conclusion: The present experiment showed that $H D L$-cholesterol level is increased by ingestion of wheat grass juice in experimental animals. Therefore, it provides the initial step for demonstrating cardio-protective effect of wheatgrass juice by increasing HDL-cholesterol level in blood in dyslipidaemic state.
\end{abstract} Keywords: Wheatgrass juice; dyslipidaemia; high density lipoprotein (HDL); Long Evans rat.

Delta Med Col J. Jan 2015;3(1):18-24

\section{Introduction}

Plasma lipoprotein levels are major modifiable risk factors for cardiovascular disease. ${ }^{1}$ On the contrary; high-density lipoproteins (HDLs) oppose atherosclerosis directly, by removing cholesterol

1. Assistant Professor, Dept. of Pharmacology \& Therapeutics, Shaheed Suhrawardy Medical College, Dhaka, Bangladesh.

2. Assistant Professor, Dept. of Anatomy, OSD, Directorate General of Health Services (DGHS), Dhaka, Bangladesh.

3. Professor \& Head, Department of Pharmacology \& Therapeutics, Dhaka Medical College, Dhaka, Bangladesh.

4. Assistant Professor, Dept. of Pharmacology \& Therapeutics, Faridpur Medical College, Faridpur, Bangladesh.

Correspondence: Dr. Rokhsana Dil Afroz.E-mail: dr.rokhsanakuhu@yahoo.com 
from foam cells, by inhibiting the oxidation of low density lipoproteins (LDLs), and by limiting the inflammatory processes that underlie atherosclerosis. Moreover, HDLs also have antithrombotic properties. Mounting clinical and experimental evidence shows that HDLs may exert multiple anti-atherogenic effects that together are consistent with a marked reduction in the risk of a morbid cardiovascular event in hyperlipidaemic state. $^{2}$

The potential hepatotoxic effect of statins, nicotinic acid and fibrates (lipid lowering agents) show elevated serum aminotransferase activity in some patients treated with these agents. ${ }^{3-6}$ Raised creatinine kinase activities may lead to rhabdomyolysis rarely in some patient treated with statins or fibrates. Fibrates also have modest risk of cholesterol gall stone. In a view to reduce the side effects of drugs, the use of herbal supplements has increased dramatically over the past 30 years. Recently, the World Health Organization estimated that $80 \%$ of people worldwide rely on herbal medicines for some part of their primary health care. ${ }^{6}$

Fresh wheatgrass (Triticum aestivum Linn.) juice had shown lipid lowering effect as well as increase in HDLs on normal rats. ${ }^{7-9}$ It is used as a health improving adjuvant in several diseases including coronary artery disease in India as folk medicine. ${ }^{7}$

However, to the best of our knowledge, experimental study on the anti-atherogenic properties of wheatgrass juice in hyperlipidaemic condition has not been done in our country previously. Hence, the current study was designed to observe the possible cardio-protective effect of wheatgrass ( $\mathrm{T}$. aestivum) juice by increasing HDLs on experimentally induced dyslipidaemic rats.

\section{Materials and method}

1. Animals: The experiment was carried out upon Long Evans rats (Norwegian strain), which were obtained from Bangladesh Council of Scientific and Industrial Research (BCSIR), Dhaka, Bangladesh. A total number of 48 adult male rats, aged 2-3 months and weighing about 140-200 grams were included in this study. They were kept in the animal house of the Department of Pharmacology \& Therapeutics, Dhaka Medical College, Dhaka, Bangladesh. The rats were kept in cages, acclimatized at $26-29^{\circ} \mathrm{C}$ and humidity, with a 12 hour light and dark cycle. They were allowed free access to standard laboratory diet and water ad libitum. Animals were randomly distributed into eight (8) groups having six (6) rats in each group.

\section{Drugs and chemicals}

a) Fresh common wheat grass juice: The wheatgrass (T. aestivum) used in this study was grown in the roof top garden. When grass was about 6 inches tall, it was cut $1 / 2$ inch above the surface of soil. Twenty grams of harvested fresh grass was grounded by grinder with $10 \mathrm{~mL}$ of sterile water and the juice was squeezed out through four layers of wet muslin cloth. The filtrate was made to $20 \mathrm{~mL}$ final volume with sterile water and administered as grass juice. Each day the fresh juice was prepared prior to administration.

b) Distilled water.

c) Standard laboratory diet.

d) Fatty mixture: $1 \%$ cholesterol diet was prepared by dissolving $1 \mathrm{gm}$ of cholesterol in $100 \mathrm{~mL}$ of olive oil. ${ }^{10}$

3. Kits for the estimation of serum cholesterol: Serum cholesterol was estimated by cholesterol liquicolor CHOD-PAP-Method (enzymatic colorimetric test with lipid clearing factor).

The experiment was carried out in the Department of Pharmacology \& Therapeutics, Dhaka Medical College, Dhaka, Bangladesh, from July 2009 to June 2010. As described earlier, a total number of 48 healthy adult male Long Evans rats were used for the present study. 


\section{Experiment design}

Group A: This control group consisting of six rats received standard laboratory diet and distilled water for 28 days.

Group B: This group of rats was fed standard laboratory diet, distilled water and $10 \mathrm{~mL} / \mathrm{kg} 1 \%$ cholesterol diet through feeding tube for 28 days, according to Amin. ${ }^{11}$

Group C: This group was fed standard laboratory diet and $10 \mathrm{~mL} / \mathrm{kg}$ grass juice.

Group D: This dyslipidaemic control group received standard laboratory diet and $10 \mathrm{~mL} / \mathrm{kg}$ $1 \%$ cholesterol diet for 28 days.

Group E: This group received 1\% cholesterol diet along with $10 \mathrm{~mL} / \mathrm{kg}$ fresh wheat grass juice to observe the preventive effect of grass juice.
Group F: This group received $10 \mathrm{~mL} / \mathrm{kg} 1 \%$ cholesterol diet for 28 days followed by $10 \mathrm{~mL} / \mathrm{kg}$ fresh grass juice for next 28 days.

Group G: This group was fed $10 \mathrm{~mL} / \mathrm{kg} 1 \%$ cholesterol diet for 28 days followed by $20 \mathrm{ml} / \mathrm{kg}$ fresh grass juice for next 28 days.

Group H: This group received $10 \mathrm{~mL} / \mathrm{kg} 1 \%$ cholesterol diet for 28 days followed by 0.14 $\mathrm{mg} / \mathrm{kg}$ Atorvastatin (a lipid lowering agent) for next 28 days, according to Jesmin. ${ }^{10}$

\section{Experiment I}

This part of the experiment was carried out on first three groups of rats to observe the effect of $1 \%$ cholesterol diet and wheatgrass juice on lipid profile of normal rat.

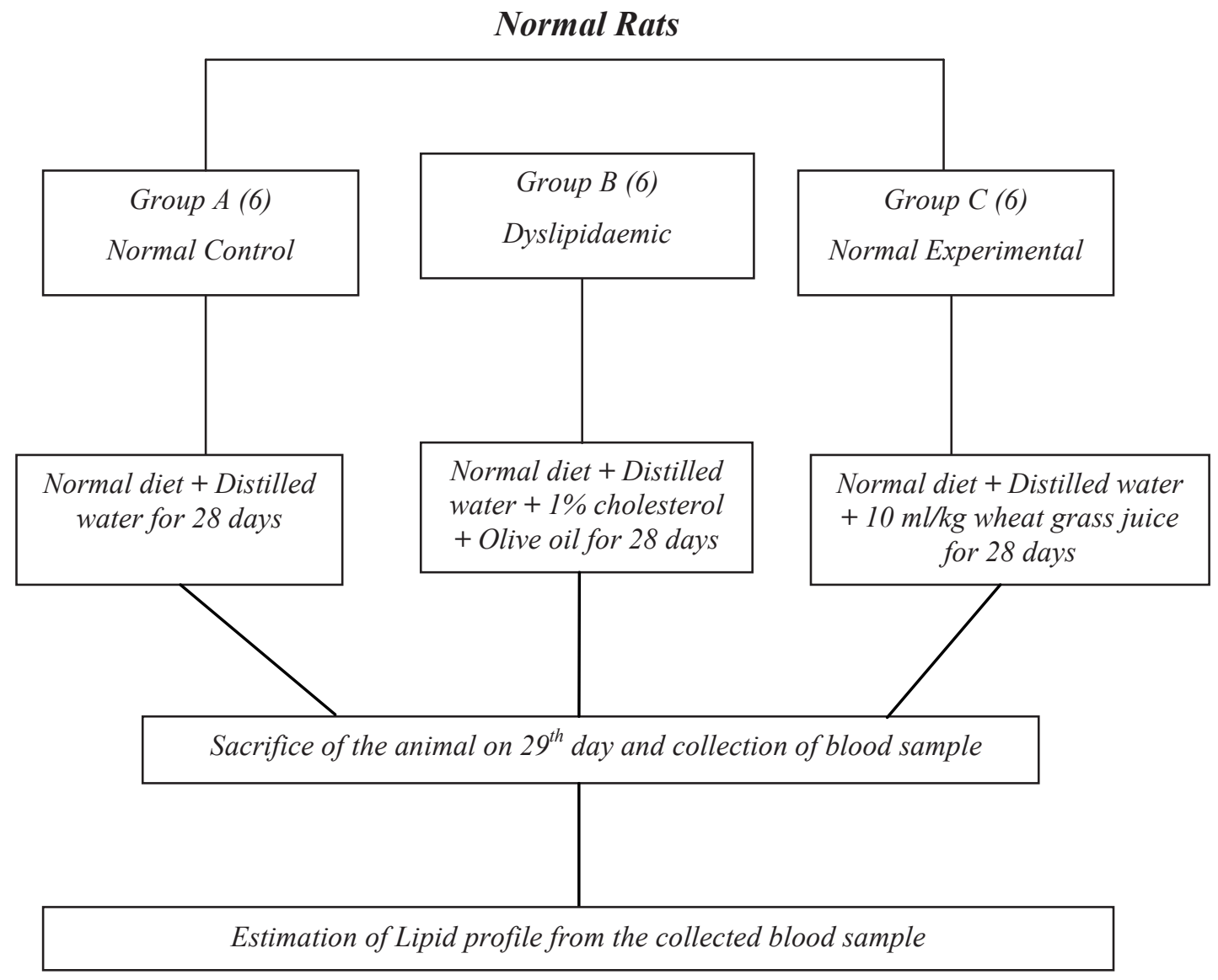

Fig. 1: Flow chart of experiment I 


\section{Experiment II}

The rats of the experiment-II were fed $1 \%$ cholesterol diet $10 \mathrm{ml} / \mathrm{kg}$ or $1 \mathrm{ml} / 100 \mathrm{gm}$ of body weight for 28 days in order to elevate plasma cholesterol level, according to Amin. ${ }^{11}$
The present study was approved by the Ethical Review Committee of Dhaka Medical College, Dhaka, Bangladesh.

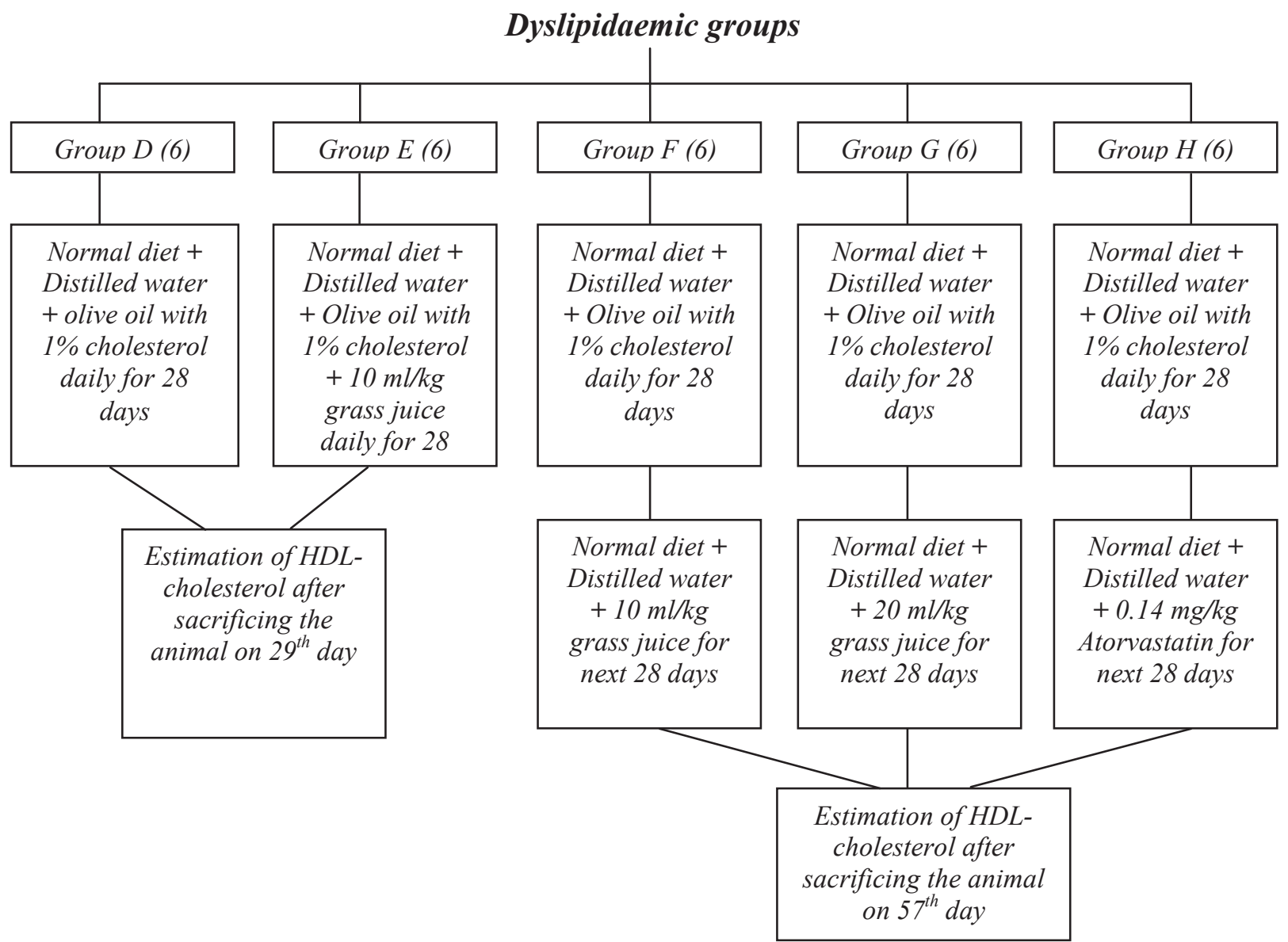

Fig. 2: Flow chart of experiment II

Each rat was made to fast for 18 hours before sacrifice and collecting blood sample. They were given only water ad libitum during the fasting period. All animals were sacrificed under ketamine anaesthesia and blood samples were taken directly from the heart. Samples were collected in the test tubes. These were kept in slanting position till blood had clotted. Serum was separated from the clot after centrifugation in the centrifuge machine. Serum was collected in small test tubes and kept at $0^{\circ} \mathrm{C}$. Then the serum was analyzed by the lipid profile kit.

\section{Results}

\section{Experiment I}

Dyslipidaemia was induced in rats by administration of $10 \mathrm{~mL} / \mathrm{kg}$ body weight olive oil with $1 \%$ cholesterol through feeding tube for 28 days. Dyslipidaemia was evident with a significant decrease in serum HDL-cholesterol level $(\mathrm{P}<0.01)$.

Effect of 1\% cholesterol diet on HDL-cholesterol of rats: The mean concentration of serum HDL-cholesterol was found to be decreased by 
$14.21 \%$ in rats treated with $1 \%$ cholesterol diet compared to the rats fed normal diet, which was statistically highly significant $(\mathrm{P}<0.01)$ (Table I).

Effect of wheat grass juice on HDL-cholesterol of normal rats: The mean serum HDL-cholesterol of $10 \mathrm{~mL} / \mathrm{kg}$ grass juice fed normal rats was increased by $4.93 \%$ than that of the laboratory diet fed control group. The result was not statistically significant (Table I).

Table I: HDL-cholesterol levels in different group of rats in Experiment I

\begin{tabular}{lccc}
\hline Group & $\begin{array}{c}\text { HDL-cholesterol } \\
(\mathbf{m g} / \mathbf{d L})(\text { Mean } \pm \text { SD })\end{array}$ & p value & $\begin{array}{c}\text { Mean percent } \\
\text { change }\end{array}$ \\
\hline $\mathbf{A}(\mathbf{n}=\mathbf{6})$ & $24.60 \pm 1.91$ & - & - \\
$\mathbf{B}(\mathbf{n}=\mathbf{6})$ & $21.00 \pm 0.80$ & B vs. A $0.002^{* *}$ & -14.21 \\
$\mathbf{C}(\mathbf{n}=\mathbf{6})$ & $25.75 \pm 1.47$ & C vs. A $0.269^{\text {ns }}$ & +4.93 \\
\hline
\end{tabular}

Comparison of HDL-cholesterol levels between groups were done by unpaired Student's ' $t$ ' test. $\mathrm{ns}=$ Not significant, $* *=$ Significant at $\mathrm{p}<0.01$.

Group A : Control

Group B : Dyslipidaemic

Group C : Laboratory diet plus grass juice

\section{Experiment II}

Effect of grass juice $(10 \mathrm{~mL} / \mathrm{kg})$ taken along with $1 \%$ cholesterol diet: In this group the mean concentration of serum HDL-cholesterol was increased by $6.47 \%$ than that of the dyslipidaemic control group, which was statistically significant $(\mathrm{P}<0.05)$ (Table II).

Effect of grass juice $(10 \mathrm{~mL} / \mathrm{kg})$ on dyslipidaemic rats: The mean serum concentration of HDL-cholesterol of the dyslipidaemic rats treated with $10 \mathrm{~mL} / \mathrm{kg}$ grass juice for 28 days were increased by $8.35 \%$, which was statistically highly significant $(\mathrm{P}<0.01)$ (Table II).

Effect of grass juice $(20 \mathrm{~mL} / \mathrm{kg})$ on dyslipidaemic rats: The mean serum concentration of HDL-cholesterol of the dyslipidaemic rats treated with $20 \mathrm{~mL} / \mathrm{kg}$ grass juice for 28 days were increased by $11.18 \%$, which was statistically highly significant $(\mathrm{P}<0.01)$ (Table II).

Effect of Atorvastatin (0.14 $\mathrm{mg} / \mathrm{kg})$ on dyslipidaemic rats: The mean serum concentration of HDL-cholesterol of the dyslipidaemic rats treated with $0.14 \mathrm{mg} / \mathrm{kg}$ Atorvastatin for 28 days were found to be increased by $14.00 \%$ than that of dyslipidaemic control group, which was statistically highly significant $(\mathrm{P}<0.001)$ (Table II).

Table II: HDL-cholesterol levels in different group of rats in Experiment II

\begin{tabular}{lccc}
\hline Group & $\begin{array}{c}\text { HDL-cholesterol } \\
(\mathbf{m g} / \mathbf{d L})(\text { Mean } \pm \text { SD) }\end{array}$ & p value & $\begin{array}{c}\text { Mean percent } \\
\text { change }\end{array}$ \\
\hline $\mathbf{D}(\mathbf{n}=\mathbf{6})$ & $21.00 \pm 0.80$ & - & - \\
$\mathbf{E}(\mathbf{n}=\mathbf{6})$ & $22.32 \pm 1.10$ & E vs. D 0.039* & +6.47 \\
$\mathbf{F ~ ( n = 6 )}$ & $22.75 \pm 1.14$ & F vs. D 0.011* & +8.35 \\
$\mathbf{G ~ ( n = 6 )}$ & $23.32 \pm 0.96$ & G vs. D 0.001** & +11.18 \\
$\mathbf{H ~ ( n = 6 )}$ & $23.92 \pm 0.93$ & H vs. D 0.0001*** & +14.00 \\
\hline
\end{tabular}

Comparison of HDL-cholesterol levels between groups were done by unpaired Student's ' $t$ ' test. $n s=$ Not significant, $*=$ Significant at $\mathrm{p}<0.05, * *=$ Significant at $\mathrm{p}<0.01, * * *=$ Significant at $\mathrm{p}<0.001$.

Group D : Dyslipidaemic

Group E : 1\% cholesterol diet plus grass juice

Group F : 1\% cholesterol followed by $10 \mathrm{ml} / \mathrm{kg}$ grass juice

Group G : 1\% cholesterol followed by $20 \mathrm{ml} / \mathrm{kg}$ grass juice

Group $\mathrm{H}: 1 \%$ cholesterol followed by Atorvastatin

Comparison of the effects of two different doses $(10 \mathrm{~mL} / \mathrm{kg}$ and $20 \mathrm{~mL} / \mathrm{kg}$ ) of grass juice: The serum HDL-cholesterol of the dyslipidaemic rat group treated with $20 \mathrm{~mL} / \mathrm{kg}$ grass juice for 28 days was found to increase by $2.70 \%$ than that of the dyslipidaemic group treated with $10 \mathrm{~mL} / \mathrm{kg}$ grass juice for the same period, which was statistically not significant (Table III).

Table III: HDL-cholesterol levels in the groups of rats taken two different doses $(10 \mathrm{ml} / \mathrm{kg}$ and $20 \mathrm{ml} / \mathrm{kg}$ ) of grass juice in Experiment II

\begin{tabular}{lccc}
\hline Group & $\begin{array}{c}\text { HDL-cholesterol } \\
(\mathbf{m g} / \mathbf{d L})(\text { Mean } \pm \text { SD })\end{array}$ & p value & $\begin{array}{c}\text { Mean percent } \\
\text { change }\end{array}$ \\
\hline $\mathbf{F ~ ( n = 6 )}$ & $22.75 \pm 1.14$ & $0.374^{\mathrm{ns}}$ & +2.70 \\
$\mathbf{G ~ ( n = 6 )}$ & $23.32 \pm 0.96$ & & \\
\hline
\end{tabular}

Comparison of HDL-cholesterol levels between group $\mathrm{G}$ and group F was done by unpaired Student's 't' test. ns $=$ Not significant.

Group F : 1\% cholesterol followed by $10 \mathrm{~mL} / \mathrm{kg}$ grass juice Group G : 1\% cholesterol followed by $20 \mathrm{~mL} / \mathrm{kg}$ grass juice 
Comparison of the effects of the wheat grass juice $(20 \mathrm{~mL} / \mathrm{kg})$ to that of with Atorvastatin $(0.14$ $\mathrm{mg} / \mathrm{kg}$ ): In the present study, the increase of serum HDL-cholesterol with the dose level of $20 \mathrm{~mL} / \mathrm{kg}$ of grass juice was found almost similar to that of Atorvastatin $(+2.64 \%)$ and was not statistically significant (Table IV).

Table IV: HDL-cholesterol levels in the groups of rats taken higher dose $(20 \mathrm{~mL} / \mathrm{kg})$ of grass juice to that of Atorvastatin in Experiment II

\begin{tabular}{lccc}
\hline Group & $\begin{array}{c}\text { HDL-cholesterol } \\
(\mathbf{m g} / \mathbf{d L})(\text { Mean } \pm \text { SD })\end{array}$ & p value & $\begin{array}{c}\text { Mean percent } \\
\text { change }\end{array}$ \\
\hline $\mathbf{G ~ ( n = 6 )}$ & $23.32 \pm 0.96$ & $0.298^{\mathrm{ns}}$ & +2.64 \\
$\mathbf{H ~ ( n = 6 )}$ & $23.92 \pm 0.93$ & & \\
\hline
\end{tabular}

Comparison of HDL-cholesterol levels between group $\mathrm{H}$ and group $\mathrm{G}$ was done by unpaired Student's ' $\mathrm{t}$ ' test. ns $=$ Not significant.

Group $\mathrm{G}: 1 \%$ cholesterol followed by $20 \mathrm{~mL} / \mathrm{kg}$ grass juice

Group $\mathrm{H}: 1 \%$ cholesterol followed by Atorvastatin

\section{Discussion}

In the present study, hypolipidaemic effect of wheat grass juice was tested on adult Long Evans rats. Dyslipidaemia was induced in rats by administration of $10 \mathrm{~mL} / \mathrm{kg}$ body weight olive oil with $1 \%$ cholesterol through feeding tube for 28 days. Dyslipidaemia was evident with a significant decrease $(p<0.01)$ in serum HDL-cholestero level. Jesmin ${ }^{10}$, Amin $^{11}$, Akter $^{12}$, Lata et al. ${ }^{13}$ and Anita \& Okokon ${ }^{14}$ achieved similar effect on lipid levels by administering similar hyperlipidaemic diet. The results of their studies are more or less in agreement with that of the present study.

The group of normal rats that took $10 \mathrm{~mL} / \mathrm{kg}$ grass juice had shown significant increase in serum HDL-cholesterol level. The result was in full agreement with that of Kothari et $\mathrm{al.}^{7}$ Administration of grass juice along with cholesterol diet also showed significant increase of serum HDL-cholesterol level than the dyslipidaemic group. It indicates preventive role of wheat grass juice against dyslipidaemia. Moreover, this effect of grass juice was found to be dose dependant. In higher dose of grass juice the effect was much more evident than that with lower dose. Kothari et al. ${ }^{7}$ also observed such changes in lipid parameters in dose related manner. In our study, increasing serum HDL-cholesterol level with the dose of $20 \mathrm{~mL} / \mathrm{kg}$ of grass juice was found almost similar to that of Atorvastatin. Overall, it showed a tremendous improvement in terms of regulating serum HDL-cholesterol level in dyslipidaemic state in rats. To the best of our knowledge, no such study has been done in our country previously. Hence, the result could not be correlated further with those of the others.

The present experiment showed that HDL-cholesterol level is increased by ingestion of wheat grass juice in experimental animals. Therefore, it provides the initial step for demonstrating cardio-protective effect of wheatgrass (T. aestivum) juice by increasing HDL-cholesterol level in blood in dyslipidaemic state. Further studies are recommended to reconfirm and identify the hypolipidaemic active principles and elucidate their mechanism of action.

\section{References}

1. Ross R. Atherosclerosis - an Inflammatory Disease. N Engl J Med. 1999;340(2):115-26.

2. Barter P. The Role of HDL-Cholesterol in Preventing Atherosclerotic Disease. Eur Heart J. 2005;7 Suppl F:S4-8.

3. Bloomfield P, Bradbury A, Grubb NR, Newby DE. Cardiovascular Disease. In: Boon NA, Colledge NR, Walker BR. Davidson's Principles and Practice of Medicine. 20th ed. London: Churchill Livingstone; 2006.p.519-646.

4. Malloy MJ, Kane JP. Agents Used in Hyperlipidemia. In: Katzung BG. Basic and Clinical Pharmacology. 10th ed. New York: McGraw-Hill; 2007.p.560-72.

5. Gowland E. Lipids and Lipoproteins. In: Mcmurry JR, Gowenlock AH, Mclauchlan DM. Practice of Clinical Biochemistry. 6th ed. New Delhi: CBS Publishers; 1988.p.452-76. 
6. Wikipedia [Internet]. Herbalism. [cited 2012 April 9]. Available from: http://en.wikipedia.org/wiki /Herbalism.

7. Kothari S, Jain AK, Mehta SC, Tonpay SD. Effect of Fresh Triticum aestivum Grass Juice on Lipid Profile of Normal Rats. Indian J Pharmacol. 2008;40(5):235-36.

8. Wikipedia [Internet]. Wheatgrass. [cited 2012 April 2]. Available from: http://en.wikipedia.org/wiki/ Wheatgrass.

9. Padalia S, Drabu S, Raheja I, Gupta A, Dhamija M. Multitude Potential of Wheatgrass Juice (Green Blood): An Overview. Chron Young Sci. 2010;1(2):23-28.

10. Jesmin S. Effects of Ctharanthus roseus Linn. on Serum Lipid Profile in Fat Fed Rats [thesis]. Dhaka: University of Dhaka; 2006.
11. Amin R. Study of the Effect of Ganoderma Lucidum on Serum Lipid Profile of Hypercholesterolaemic Rats [thesis]. Dhaka: University of Dhaka; 2009.

12. Akter R. Study of the Effect of Garlic on Blood Sugar and Serum Cholesterol Level in Normal Rats and Serum Cholesterol Level in Fat Fed Rats [thesis]. Dhaka: University of Dhaka; 1982.

13. Lata S, Saxena KK, Bhasin V, Saxena RS, Kumar A, Srivastava VK. Beneficial Effects of Allium sativum, Allium cepa and Commiphora mukul on Experimental Hyperlipidemia and Atherosclerosis a Comparative Evaluation. J Postgrad Med. 1991;37(3):132-35.

14. Anita BS, Okokon JE. Effect of Leaf Juice of Catharanthus roseus Linn. on Cholesterol, Triglyceride and Lipoprotein Levels in Normal Rats. Indian J Pharmacol. 2005;37(6):401-402. 